\title{
A CLINICAL, PATHOLOGICAL AND BIOCHEMICAL STUDY OF AMYLOID NEPHROSIS.
}

\author{
$\mathrm{BY}$ \\ G. C. LINDER, M.D., M.R.C.P., J. MAXWELL, M.D., M.R.C.P., and \\ F. H. K. GREEN, M.B., B.S., M.R.C.P.
}

(From the Medical Unit, St. Bartholomew's Hospital, London.)

The conception of a degenerative form of nephritis as opposed to the common inflammatory form, whether justified or not, has been the source of many valuable observations on the clinical, chemical and histological aspects of the subject. The term " nephrosis " was introduced by Müller $\left(^{1}\right)$ to indicate the purely degenerative form, and since the degeneration is frequently of the fatty type, the term "lipoid nephrosis" has been used by many writers on the subject. It appears, however, that there is no hard and fast line between ordinary glomerulonephritis and nephrosis, and that all combinations of glomerular and vascular inflammation with tubular degeneration may be found. Nevertheless it remains convenient to distinguish a group in which the signs of inflammation are conspicuously small.

In this group of cases it is found that there is a remarkable absence of cardiovascular abnormalities, such as raised blood pressure, cardiac hypertrophy, retinal hæmorrhages and exudates, hæmaturia and anæmia, but that there is an equally remarkable liability to œdema. The fact that complete recovery may occur even after years of obstinate œedema and proteinuria makes the recognition of this condition of more than academic interest from the aspect of prognosis. Biochemical studies show that there is unimpaired ability to excrete urea and that the blood urea is sometimes exceptionally low. The blood uric acid is slightly raised. Water and sodium are excreted with difficulty, and the balance of water and salts in the tissues is upset $\left({ }^{2}\right)$. The albumin of the plasma is greatly reduced, more so than in glomerulonephritis with œdema, and the globulin is slightly increased $\left({ }^{3}\right)$. The plasma is often milky in appearance and contains an excess of fatty acids and cholesterol.

In slight and temporary cases the pathological lesion is confined to cloudy swelling of the parenchyma of the kidney, but in graver cases it passes into a form of "large white (or yellow) kidney" in which quantities of simple and anisotropic fat appear in the epithelium of the tubules and later in the interstitial tissues. Occasionally the deposits of fat are so extensive that the condition is that described by McNee, under the name of " myelin kidney "( $\left.{ }^{4}\right)$. The deposits of cholesterin provoke an inflammatory interstitial reaction and the denuded tubules disappear with degeneration of their glomeruli. The kidney as the result of these changes becomes small, and fibrous tissue develops in it. Ultimately a "nephrotic contracted kidney" is produced (Volhard and $\left.\operatorname{Fahr}\left({ }^{5}\right)\right)$, and this is associated with failure of renal function but not with 
increase of blood pressure or its concomitants. The final stage is rarely seen, for most of the victims of this disease succumb to the perils of their waterlogged state or to an intercurrent infection.

Two other pathological states not uncommonly complicate the picture, namely, arteriosclerosis and amyloid disease. Amyloid disease of the kidney may occur apart from lipoid nephrosis and in that event its sole symptom is proteinuria. When it is associated with nephrosis the symptoms are those of uncomplicated nephrosis, from which therefore it cannot be recognised during life (Volhard and Fahr $\left(^{5}\right)$ ).

The case reported here was diagnosed as one of "nephrotic contracted kidney" and the presence of amyloid, though suggested by the history, was unrecognised. Detailed studies of the clinical course and the chemistry, particularly of the inorganic radicles, of this late stage of the condition are scanty, and it is for this reason that the case is presented.

\section{Case.}

History. The patient was an undersized and deformed boy of 13 years. At the age of four he had mastoid operations performed on both ears; the left healed but the right continued to discharge from time to time. A few weeks after the operation his face became puffy and his legs œdematous. In the following years the swelling had come and gone and he had been in hospital for it more than once. In 1925 he was sent to St. Bartholomew's Hospital for treatment of his ear. On examination his neck was found to be rigid and his right knee full of fluid; for this latter and for his stunted growth he was referred to the orthopædic department where it was found that he had odema and proteinuria.

He was admitted to a medical ward on October $29 \mathrm{th}, 1925$. He complained of nothing except the swelling. His weight was 74 pounds. He had scabies. The face was pale and puffy but the mucous membranes were of good colour. The neck was rigidly fixed and no rotation of the head on the trunk was possible; he peeped out of the corners of his eyes. The optic discs were blurred but there were no hæmorrhages or exudates into the retina ; the veins were engorged and the vessels tortuous. Both ear drums were perforated and from the right ear there was a copious discharge of pus; there was a small sinus over the right mastoid. Tonsils and pharynx were healthy. He was pigeon-chested with wide and prominent subcostal angle. It was difficult to estimate the size of the heart exactly, but the apex was in the fourth space 3 in. from the midline and the cardiac impulse was somewhat forcible. The heart sounds were not abnormal. The blood pressure registered $112 / 72 \mathrm{~mm}$; the arteries were not thickened. The lungs were normal. The abdomen was generally distended but without definite signs of free fluid. The liver, spleen and kidneys were not palpable. There was œedema of the whole body, especially of the face, legs and sacral region, and a painless effusion into the right knee joint. Blood examination : red cells $4,800,000$, hæmoglobin 78 per cent., white cells 10,800 , urea $27 \mathrm{mg}$. per $100 \mathrm{cc}$., Wasserman and Sigma tests, negative. Urine : S.G. 1,005 to 1,030, pale and clear, protein 0.3 to 0.8 per cent., no sugar; quantity 200 to 1,000 cc. a day. Urine deposit contained a few pus cells, an occasional red blood cell and a few granular casts. Urea feeding test (14.11.25) : maximum concentration, 2.5 per cent. in the first hour ; maximum output, $1.4 \mathrm{gm}$. in second hour.

Course and Treatment. The œdema decreased somewhat soon after admission but remained massive. Urea therapy (10 gm. a day) was given from November 16th to December 24th; it was quite ineffectual although the blood urea increased to $90 \mathrm{mg}$. A few days after it was discontinued, the blood urea had fallen again to $39 \mathrm{mg}$. On December 9 th an operation was performed on the right mastoid, after which the discharge from the ear almost disappeared. 
The knee became very tense and painful, and it was aspirated on several occasions ; the fluid obtained was purulent, but it was sterile and its inoculation into a guinea pig did not result in tuberculosis. X-rays did not reveal any disease in the knee, and showed that the stiffness of the neck was due to fusion of the laminæ of the vertebræ.

On January 9th, 1926, traces of sugar appeared in the urine. Until this date daily examination of 24-hour specimens had failed to show any sugar, but from this time onwards it was always present in small but definite amount. A blood-sugar curve after 50 grams of dextrose showed a rise from a fasting figure of 0.9 per cent. to a maximum of 0.11 per cent. at the end of an hour; the sugar in the urine was not appreciably increased. A lowering of the threshold for sugar was therefore present, similar to the lowering of the threshold sometimes seen in the terminal stages of glomerulonephritis $\left({ }^{6}\right)$.

From December 28th a strict salt-free diet was given, the amount of fluid taken being limited as before to $1,200 \mathrm{cc}$. a day. The régime was very successful in reducing the œdema and in improving his general condition. He became free of œdema. On February 17 th he was not so well, and on the following days he developed headache, vomiting, drowsiness and twitching of muscles. The breathing becameslow and deep. Ageneralerythematous rash appeared. The output

\section{CHART I.}

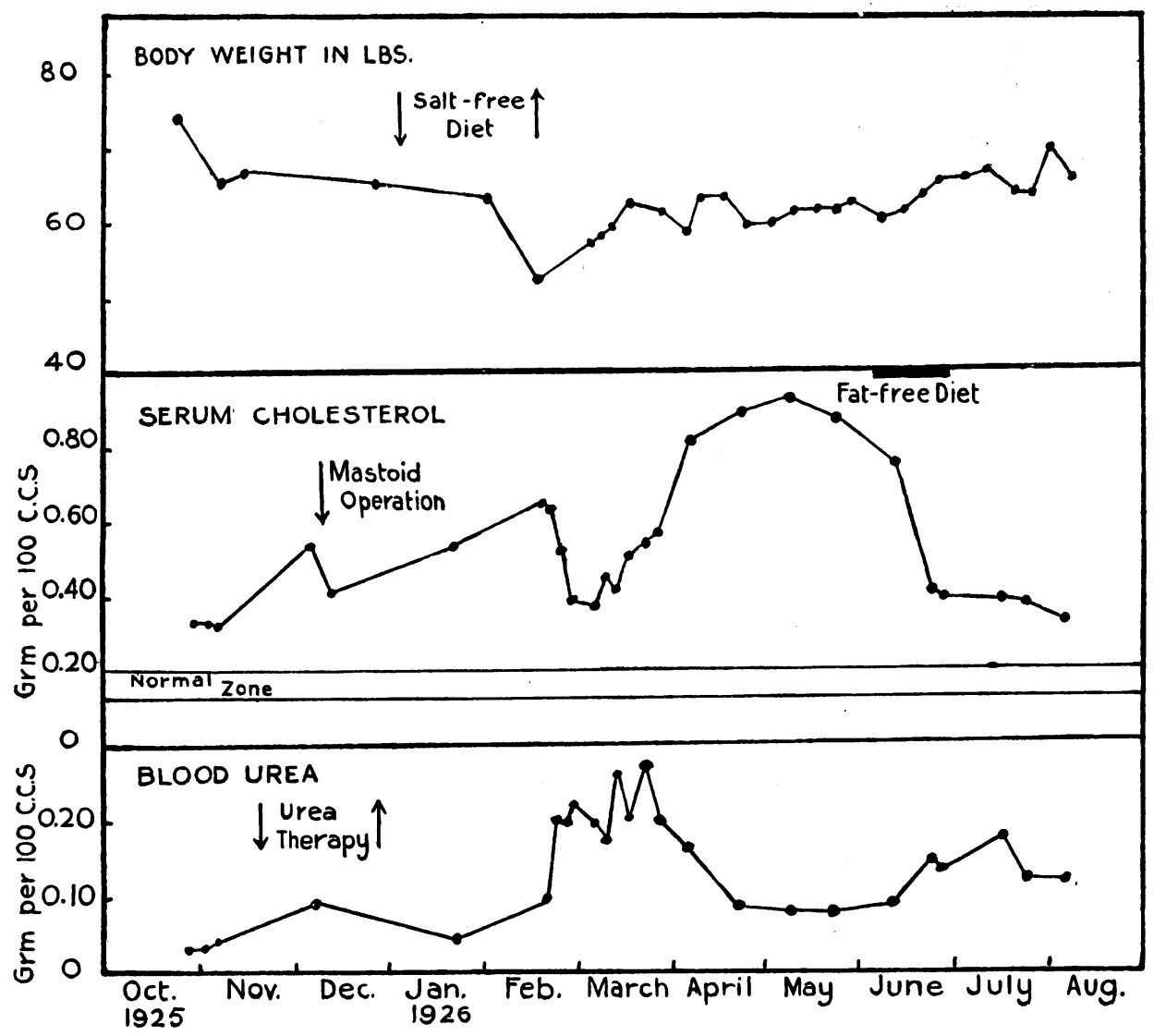

Chart I. The three curves indicate the variations in body weight, serum cholesterol and blood urea. 
of urine was only 300 to 500 cc. a day, but he appeared desiccated, not œdematous, and his weight had fallen to 52 pounds. The blood urea which was $90 \mathrm{mg}$. on 18th, had risen to $199 \mathrm{mg}$. on 24th, and the serum gave Andrewes's diazo reaction of uræmia $\left(^{7}\right)$. He became rapidly worse and was thought to be dying. From the commencement of this change for the worse he was encouraged to take extra fluids, and on the 22nd this was supplemented by giving rectal salines. Food restrictions were relaxed.

CHART $1 I$.

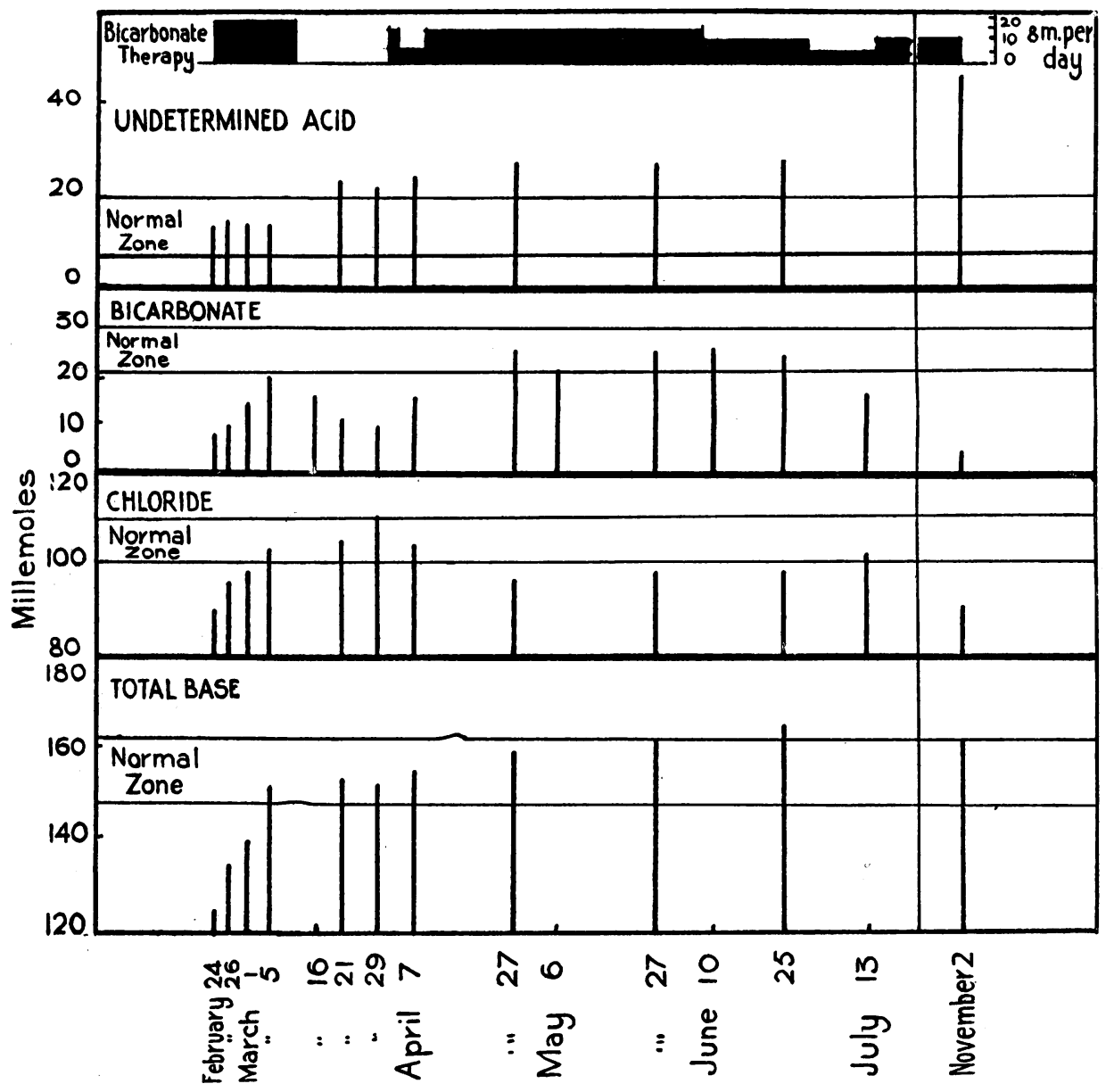

Chart II. The four series of columns indicate the concentrations of " undetermined acids," bicarbonate, chloride and total fixed base in the serum in millemoles per litre. The zone of normal variations is indicated by the two lightly drawn horizontal lines in each compartment of the chart. Bicarbonate therapy is shown by the solid figures in the uppermost compartment.

On February 24th a complete examination of the inorganic constituents of the serum revealed an extremely abnormal state. The $\mathrm{CO}_{2}$ content had fallen to 14 volumes per cent. and the $p \mathrm{H}$ to $7 \cdot 05$, so that there was present a very extreme uncompensated acidosis (acidæmia). In addition to this there was a great reduction of the total inorganic bases and chlorides. The condition was interpreted as a combination of uræmic acidosis with a deficiency of base and chloride due to the prolonged salt-free diet. (Chart II and Table.) 
TABLE I.

Variations in total acid-base balance in the serum of H.B.

\begin{tabular}{|c|c|c|c|c|c|c|c|c|c|}
\hline \multirow[b]{2}{*}{ Date. } & \multirow[b]{2}{*}{ Protein. } & \multirow[b]{2}{*}{$p \mathrm{H}$} & \multicolumn{4}{|c|}{ Base bound by } & \multirow[b]{2}{*}{$\begin{array}{l}\text { Total } \\
\text { Base. }\end{array}$} & \multicolumn{2}{|c|}{ Base bound by } \\
\hline & & & $\mathrm{HCO}_{3}$ & $\mathrm{Cl}$. & $\mathrm{PO}_{4}$ & Protein & & $\begin{array}{l}\text { Determined } \\
\text { Acids. }\end{array}$ & $\begin{array}{l}\text { Undetermined } \\
\text { Acids. }\end{array}$ \\
\hline & gm. \% & & $\mathrm{mM}$. & $\mathrm{mN}$ & $\mathrm{mM}$. & $\mathrm{m} \mathbf{M}$. & $\mathrm{mM}$. & mM. & mM. \\
\hline $24 / 2 / 26$ & & $7 \cdot 05$ & $8 \cdot 1$ & $89 \cdot 5$ & $7 \cdot 0$ & (7) & 124 & 112 & 12 \\
\hline $26 / 2 / 26$ & & & 10 & $96 \cdot 0$ & (7) & (7) & 134 & 120 & 14 \\
\hline $1 / 3 / 26$ & & $7 \cdot 14$ & $14 \cdot 9$ & 98 & (7) & (6) & 139 & 126 & 13 \\
\hline $5 / 3 / 26$ & $4 \cdot 0$ & & 20 & 103.5 & $4 \cdot 2$ & 6 & 151 & 134 & 17 \\
\hline $16 / 3 / 26$ & & & 15 & & $4 \cdot 3$ & & & & \\
\hline $21 / 3 / 26$ & & $7 \cdot 17$ & $11 \cdot 5$ & 105 & (4) & (6) & 152 & 126 & 26 \\
\hline $29 / 3 / 26$ & & $7 \cdot 16$ & $8 \cdot 7$ & 110 & (4) & (6) & 151 & 129 & 22 \\
\hline $7 / 4 / 26$ & & $7 \cdot 20$ & $15 \cdot 9$ & 104 & (4) & (6) & 154 & 130 & 24 \\
\hline $27 / 4 / 26$ & & $7 \cdot 41$ & $26 \cdot 0$ & 96 & (4) & (7) & 159 & 133 & 26 \\
\hline $6 / 5 / 26$ & $3 \cdot 8$ & $7 \cdot 33$ & $21 \cdot 5$ & & $3 \cdot 5$ & $6 \cdot 5$ & & & \\
\hline $27 / 5 / 26$ & $3 \cdot 8$ & $7 \cdot 24$ & $26 \cdot 1$ & 98 & $4 \cdot 1$ & $6 \cdot 5$ & 161 & 135 & 26 \\
\hline $10 / 6 / 26$ & & & 28 & & & & & & \\
\hline $25 / 6 / 26$ & $4 \cdot 7$ & $7 \cdot 24$ & $24 \cdot 4$ & 99 & $4 \cdot 0$ & $7 \cdot 8$ & 164 & 135 & 29 \\
\hline $13 / 7 / 26$ & & & 17 & 101 & & & & & \\
\hline $2 / 11 / 26$ & & $7 \cdot 15$ & $4 \cdot 6$ & 91 & $11 \cdot 5$ & (7) & 161 & 114 & 47 \\
\hline
\end{tabular}

( ) Figures in brackets were not determined on the date given, but are approximated from the closest data. To obtain the figure for $\mathrm{mm}$. of base bound by protein it was necessary to know both protein concentration and $p \mathrm{H}$; it was then calculated from the formula $[\mathrm{BPs}]=0.068$ Ps] $(p \mathrm{H}-4 \cdot 80)$. (Van Slyke, Wu and McLean, Journ. Biol. Chem., 1923, LVI, 765.)

Fluids were then forced upon him to the extent of 2,500 cc. a day, and 5 grams of sodium bicarbonate were given four times a day. The result was a striking relief of his symptoms, but in the course of a few days the odema returned to a very great extent. The inorganic bases gradually increased in the serum but it was three weeks before the normal level was attained. Chloride increased in a similar way, but the $\mathrm{CO}_{2}$ was still below normal at $48 \cdot 7$ vols. per cent. when it was thought desirable to stop giving the bicarbonate on account of the increasing œdema (March 8th). To counteract this the fluid intake was reduced to 1,200 cc. and the diet was moderately restricted generally and in respect to salt. At this time he was comfortable and happy, and his appetite was good although he still vomited occasionally. The blood urea remained in the region of $200 \mathrm{mg}$. The $\mathrm{CO}_{2}$ content had fallen to 28 vols. by March 21 st and an attempt to counter this fall was made by giving disodium phosphate. A moderate diuresis was the result, but the $\mathrm{CO}_{2}$ content continued to fall.

On April lst the phosphate was replaced by bicarbonate in doses of 15 grams a day. Two days later tetany was present. It was attributed to an alkalosis due to excess of bicarbonate, but unfortunately no blood examination was made. The tetany was quickly removed by a dose of 10 grams of ammonium chloride and the bicarbonate was reduced to 5 grams a day. 
The vomiting had not been at all severe for some weeks and by this time had ceased. Four days later the serum contained 38 vols. of $\mathrm{CO}_{2}$ and its $p \mathrm{H}$ was $7 \cdot 20$, so that it appeared improbable that there had been an alkalosis severe enough to have been the cause of tetany. The serum calcium was low, $6 \cdot 1 \mathrm{mg}$. per cent., but the significance of this low figure as possibly productive of the tetany is discounted by the fact that the serum protein was also very low, 3.8 per cent. Salvesen and $\operatorname{Linder}\left({ }^{8}\right)$ found that the serum calcium in nephritis with odema always fell with the protein without the development of tetany ; under these conditions the serum calcium was found as low as $6 \cdot 3 \mathrm{mg}$. It appeared possible that with this low concentration of calcium and protein the body might have become more sensitive to decrease of hydrogen ions, and that the tetany might have been evoked at the normal blood reaction. To gain information on this point, the bicarbonate was increased on 13 th to 15 grams a day, but although the $\mathrm{CO}_{2}$ increased to 61 vol. and the $p \mathrm{H}$ to 7.41 , the tetany did not recur.

In June the daily dose of bicarbonate was reduced to 10 grams and then to 5 grams. The $\mathrm{CO}_{2}$ began to fall after the second reduction, so the dose was again increased to 10 grams.

In May he was up and allowed out in the hospital square. The blood urea had fallen in April from $200 \mathrm{mg}$. to $80 \mathrm{mg}$. at which level it remained till June when it began to rise again. In July there was no œdema except some puffiness of the face. His basal metabolism was -23 per cent.

He went home on August 12th. Since admission the blood pressure had not increased and the heart had not enlarged. The urine still contained a large amount of protein but no red cells or casts. The hæmoglobin had fallen to 38 per cent. during his uræmic attack and was the same in August; the red cells numbered 1,850,000. The blood urea was $118 \mathrm{mg}$. The specific gravity of the urine varied only from 1,008 to 1,014 .

He remained in the same condition, taking bicarbonate regularly, until the end of October when he caught an acute coryza. After two days of vomiting and diarrhœa he became much worse and was brought to hospital. He was then in a moribund state. There were signs of bronchopneumonia in both lungs. Dyspnœa was extreme. Neither liver nor spleen was palpable. There was no ascites, and no œdema was present except for moderate pitting over the shins. The $\mathrm{CO}_{2}$ content of the serum had fallen to the very low figure of 11 volumes per cent. The $\mathrm{pH}$ was 7.15. The non-protein nitrogen was $187 \mathrm{mg}$. per cent.

He died 30 hours after admission. The clinical diagnosis was chronic nephritis (chronic nephrosis in final stage of contraction) bronchopneumonia.

\section{Autopsy.}

The body was poorly nourished. The face was puffy, but there was no other œdema.

Heart, $7 \mathrm{oz}$. Pericardium was obliterated by fine. recent adhesions. No hypertrophy, slight dilatation. Valves, aorta and coronary arteries, healthy. Pleurce. Right sac was obliterated by soft adhesions in the meshes of which was yellow pus. Left was similar, but there was a collection of $150 \mathrm{cc}$. of pus at the back of the lower lobe. Lungs : both contained areas of confluent bronchopneumonia. Peritoneum: healthy. Liver: rather large and pale with rounded edges. Spleen : $6 \mathrm{oz}$., somewhat enlarged and firm; on section it was bloodless and the Malpighian corpuscles were enlarged and translucent ("sago" spleen).

Kidneys. R. $2 \frac{3}{4}$ oz., L. $2 \frac{1}{2}$ oz. Both kidneys were much reduced in size. The capsule stripped with a little difficulty being bound to the cortex by fine adhesions. The exposed surface was very finely granular and of a pale yellow colour. On section the pelvic fat was seen to be inoreased, but the pelvis was not dilated. The cortex was moderately decreased in width, in some parts extremely so ; it was yellowish grey in colour and in it translucent specks could be seen representing the glomeruli. There appeared to be both fibrous and fatty changes. The pyramids were somewhat atrophied, but retained their normal colour and markings. The blood vessels were not abnormally apparent on the cut surface. Bladder and ureters : healthy.

Brain. No examination permitted. 
The laminæ of the cervical vertebræ were fused, but the bodies of the vertebræ and the intervertebral discs were sound. The right thigh and calf were wasted, and the knee joint showed no changes except a small erosion of the articular cartilage.

The heart's blood contained pneumococci.

Histological Report.

The Kidneys. Sections were stained with methyl violet (for amyloid degeneration); hæmotoxylin and oesin; Van Gieson; hæmotoxylin and Sudan III (frozen sections prepared by Gaskell's gelatin technique $\left.{ }^{9}\right)$. Fresh sections also were examined under a polarising microscope.

As will be seen from the illustrations the sections of kidney presented a remarkable appearance. The most striking thing about them was the appearance of the glomeruli which, almost without exception, were enormously swollen and homogeneus. In size each appeared about twice the normal. Stained with hæmotoxylin and eosin they assumed a uniform pinkish tinge. With hæmotoxylin and Sudan III they remained unstained, except for certain areas of fatty degeneration in many of them, and for a few endothelial cells in each which seemed to have escaped the general destruction. With methyl violet they gave the characteristic pink colour of amyloid material.

The Bowman's capsules were distended in every instance, and in places a small amount of " crescent formation" was to be seen. The epithelium of the tubules showed varying stages of fatty degeneration and atrophy. In a few small zones some apparently normal tubules were present; in others the contracting interstitial tissue had given rise to a few minute cysts.

The interstitial tissues showed a moderately active infiltration with round cells and fibroblasts, but the Van Gieson preparations revealed relatively little formed fibrous tissue. The smallness of the kidneys appeared to be due rather to degeneration and atrophy than to extensive inflammatory fibrosis.

The arteries showed changes of three kinds:-(1) Deposits of amyloid material, staining pink with methyl violet and best seen in the tunica media of the smaller vessels ; (2) intimal thickening and hyaline change in the interlobular arteries ; (3) endothelial proliferation and fatty degeneration in the intima of the arterioles. Changes (2) and (3) were precisely similar to those occurring in older patients with diffuse hyperplastic arteriosclerosis and high blood pressure. Evans $\left({ }^{10}\right)$ has pointed out that it is not unusual to find these lesions confined to the kidney in many types of nephritis and that a diagnosis of diffuse hyperplastic sclerosis cannot be made unless they are present in other organs, notably the spleen. In this patient sections of the spleen, stained for fat, failed to show such lesions.

The appearances in the kidney, then, were those of a wide-spread degeneration and the inflammatory element was not marked. The nature of the degenerate material was amyloid with a fair amount of fat. Examination of fresh sections with a polarising microscope demonstrated a little doubly refracting material in the glomeruli and the tubules, but this was not present to such an extent as to justify the term " myelin kidney."

Sections from the liver and spleen showed the presence of amyloid deposits; the liver also showed fatty degeneration.

\section{General.}

\section{Discussion.}

From the definite history of œdema recurring repeatedly during the preceding nine years, it seemed certain that chronic renal disease had been present for that time, and the atrophied state of the kidneys supported the opinion that the duration of the process had been a lengthy one. Since the œedema occurred first in weeks following a mastoid operation and its recurrences were associated with persistent aural sepsis, it seems very probable that this sepsis was the origin of the disease and the cause of its progressive course, 
The discovery of amyloid degeneration was to be expected in a condition secondary to prolonged septic absorption, and should have been more definitely anticipated during life. The unusual sterile suppuration in the knee joint was considered to be another secondary phenomenon, and it is noteworthy that the trouble in this joint subsided when the primary focus in the ear had been attended to.

In the combination of a well marked tendency to odema with a complete absence of hypertension and cardiac hypertrophy the case complied with the requirements for the diagnosis of " nephrosis." It was therefore an example of that condition in the terminal stage which is so rarely seen. It is of interest that with the onset of urea retention and uræmia the blood pressure did not rise although there was no evidence of heart failure to hinder it from doing so. The renal insufficiency was accompanied by wasting and anæmia as in glom. erulonephritis, and the derangement of acid-base balance was profound.

\section{Cholesterol (Chart I.)}

The concentration of the plasma cholesterol was followed by the method of Myers and Wardell( $\left.{ }^{11}\right)$; this method gives maximum normal values of 0.20 per cent. On admission (Oct. 1925) the plasma contained 0.33 per cent. and by December this had increased to 0.55 . From this time the cholesterol rose steadily, reaching a maximum of 0.92 in May 1926. This steady rise was interrupted twice; first by a fall to $\mathbf{0 . 4 0}$ following the mastoid operation, and secondly by an irregular depression occupying the seven weeks of uræmia and acidosis in February and March. With the fall of tho blood urea the cholesterol rose rapidly and attained the level to which it would have reached if its former rate of increase had not been interrupted. After reaching its maximum the cholesterol remained fairly constant for three weeks ; a fat-free diet was then given, and this was accompanied by a fall to $0 \cdot 40$ per cent. in the next three weeks. On returning to a normal diet, the cholesterol did not rise in the six weeks following. No determinations were made from then till the time of death when the cholesterol had risen to 0.60 per cent. in spite of the presence of a severe infection.

It is well established that in hydræmic nephritis the plasma cholesterol is increased, but the meaning of this occurrence remains obscure. As shown in the present case the increase is not always proportional to the degree of œdema ; for example, the highest cholesterol figure was obtained when no cedema could be recognised. The depression of the cholesterol which accompanies the uræmic state was also shown, and the possibility arises that the excessive cholesterol may be capable of reduction by a fat-free diet such as was recommended by Epstein for the treatment of these œdematous patients $\left({ }^{12}\right)$.

\section{Total Acid-Base Equilibrium.}

In the studies of this patient's serum we have an excellent example of the changes which occur in the balance of acid and base during the terminal stage of nephritis. 
According to Peters $\left({ }^{13}\right)$ the average amount of base per litre of serum is equivalent to 156 millemoles of monovalent alkali. Of this an average of 103 millemoles are combined with chloride, 26 with bicarbonate, 3 with phosphate and 11 with the serum proteins which act as acids at the blood reaction. 13 millemoles remain unaccounted for, and since at the almost neutral reaction of the serum all the base must be combined with acid, it follows that there must be 13 mille-equivalents of acid substances in the serum over and above those already enumerated. These "undetermined" acids have not been identified but they comprise organic acids and a small amount of sulphate. The maximum concentration of these undetermined acids observed by Peters in his series of normals was $19.8 \mathrm{mM}$.

Bulger, Peters, Eisenman and Lee $\left({ }^{14}\right)$ showed that in the later stages of nephritis the undetermined acids were greatly increased. Their steady rise in the present case was of great significance. From Table I and Chart II it may be seen that, during the crisis through which the patient passedin February, these substances remained within the normal limits of concentration. But from the end of March they increased progressively in spite of improvement in the clinical state and of a falling blood urea. By June they had reached a titre of $29 \mathrm{mM}$. and just before death one of $47 \mathrm{mM}$.

Originally the term "alkali reserve" was applied to the base bound by bicarbonate, but it now appears that the base bound by chloride may become available for binding extraneous acids instead of, or as well as, that bound by bicarbonate. It will be seen from the chart that both these compartments of alkali reserve were encroached upon, once in February because of a deficiency of total base, and again in November because of the great excess of other acids, the concentration of base being normal. On the first of these occasions the condition was corrected by giving salt and sodium bicarbonate. When the latter was discontinued the serum bicarbonate at once fell and its place was taken by chloride and "undetermined" acid. When alkali was given again the bicarbonate rose and the chloride fell below normal The sum of chloride and bicarbonate tends to be more constant than either of its components.

In considering these changes in the alkali reserve of the serum it must not be forgotten that in whole blood between 70 and 80 per cent. of the total buffering power is due to the hæmoglobin which at blood $p \mathrm{H}$ acts as a weak acid. The base bound by hæmoglobin varies with the total hæmoglobin, its degree of saturation with oxygen, and the $p \mathrm{H}$ within the cells $\left({ }^{15}\right)$. In the present case the great reduction in hæmoglobin in the later stages and the low $p H$ indicated a great fall in this, the most important, reserve of alkali.

It seems very probable that the upset of February was precipitated by an unduly prolonged treatment with salt-free diet. Allen $\left({ }^{16}\right)$ has called attention to the occasional production of collapse in patients with hypertension who have been restricted to less than one gram of salt per day; he maintained that no salt-free diet was effective unless such accidents did occasionally occur. The present instance is the first experience we have had of ill effects from this 
treatment although numerous patients with œdema and a few with hypertension have taken for months diets on which the excretion of sodium chloride was less than a gram a day. In the present case the hypothesis of salt starvation would explain the desiccated appearance of the patient and also the chemical condition of extreme reduction of serum base $(125 \mathrm{mM}$.) with corresponding fall in chloride and bicarbonate. The recovery of the patient coincident with their rise when salts were given lends a little further support to this opinion.

We attach little importance to the $p \mathrm{H}$ determinations because in some of the earlier observations it was impossible to obtain blood without stasis, although by means of hot arm baths this was avoided as much as possible. Fortunately on February 24th this difficulty did not occur.

The final figure for the $\mathrm{CO}_{2}$ content is perhaps worthy of special comment ; 11 volumes per cent. is one of the lowest contents recorded in nephritis.

\section{SUMMARY.}

1. This paper contains a clinical, histological and biochemical study of a case of "amyloid nephrosis" in its later stages.

2. The total acid-base equilibrium and the cholesterol in the serum were followed closely, and their clinical values are discussed.

3. The occurrence of tetany and of symptoms of salt deprivation are reported.

In conclusion we desire to express our thanks to Professor F. R. Fraser for the opportunity of studying this case, and to Dr. Geoffrey Evans for his kindness in lending us the reproductions of the sections of the kidney. One of us (G. C. L.) is also indebted to the Medical Research Council for a grant.

\section{METHODS EMPLOYED.}

Blood urea : Archer, H. E., and Robb, G. D., Quart. J. Med., Oxf., 1925, XVIII, 274.

Cholesterol : Myers, V. C., and Wardell, E. L., J. Biol. Chem., Baltimore, 1918, XXXVI, 147.

$p \mathrm{H}$ : Hastings, A. B., and Sendroy, J., ibid, 1924, LXI, 695.

$\mathrm{CO}_{2}$ : Van Slyke, D. D., and Niell, J. M., ibid, 1924, LXI, 523.

Inorganic phosphorus : Benedict, S. R., and Theis, R. C., ibid, 1924, LXI, 63.

Chloride : Van Slyke, D. D., ibid, 1923-24, LVIII, 523.

Fixed base : Stadie, W. C., and Ross, E. C., ibid, 1925, LXV, 735.

Calcium : Kramer, B., and Tisdall, F. F., ibid, 1921, XLVII, 475.

\section{REFERENCES.}

1. Muller, Fr., Verhandl. d. deut. path. Gesellschaft, 1905.

2. Volhard, F., Die doppelseitigen hamatogenen Nierenkrankungen, Berlin, 1918.

3. Linder, G. C., Lundsgaard, C., and Van Slyke, D. D., J. Exper. Med., Balt., 1924, XXXIX, 887.

4. McNee, J. W., J. Path. and Bact., Edin., 1922, XXV, 425.

5. Volhard, F., and Fahr, T., Die Brightsche Nierenkrankeit, Berlin, 1914.

6. Linder, G. C., Hiller, A., and Van Slyke, D. D., J. Clin. Investigation, Balt., 1925, I, 247.

7. Andrewes, C. H., Lancet, Lond., 1924, LVIII, 590.

8. Salvesen, H. A., and Linder, G. C., J. Biol. Chem., Balt., 1923, 1923-4, 617 and 635. 
9. Gaskell, J. F., J. Path. and Bact., Camb., 1911-12, XVI, 287.

10. Evans, G., Quart. J. Med., Oxf., 1921, XIV, 215.

11. Myers, V. C., and Wardell, E. L., J. Biol. Chem., Balt., 1918, XXXVI, 147.

12. Epstein, A., Amer. J. Med. Sci., Philad., 1917, CLIV, 638, and 1922, CLXIII, 167.

13. Peters, J. P., Bulger, H. A., Eisenman, A. J., and Lee, C., J. Biol. Chem., Balt., 1926, LXVII, 141.

14. Bulger, H. A., Peters, J. P., Eisenman, A. J., and Lee, C., J. Clin. Investigation, Balt., 1926, II, 213.

15. Van Slyke, D. D., Hastings, A. B., and Neill, J. M., J. Biol. Chem., Balt., 1922, LIV, 507.

16. Allen, F. M., and Sherill, J. W., J. Metabolic Res., Morristown, 1922, II, 429. 